\title{
IMPLEMENTASI PRAKTIK PENGALAMAN LAPANGAN (PPL) MAHASISWA PROGRAM STUDI PENDIDIKAN BAHASA INGGRIS FKIP UNIVERSITAS ISLAM LAMONGAN
}

\author{
Fathurrahman; Abdullah Farih \\ fath@unisla.ac.id; abdullahfarih@unisla.ac.id \\ Pendidikan Bahasa Inggris, FKIP, Universitas Islam Lamongan
}

\begin{abstract}
Abstrak
Praktik Pengalaman Lapangan (PPL) dirancang untuk mahasiswa semester akhirsebagaiwadah pelatihan para calon guru agar memiliki kecakapan keguruan secara lengkap dan terintegrasi. Program ini meliputi pelatihan praktek mengajar secara langsung dan latihan melaksanakan tugas serta layanan kependidikan lainnya. Pelaksanaannya dilakukan sesudah mahasiswa memperoleh bekal yang memadai dalam berbagai bidang yang berkaitan dengan tugasnya sebagai guru, berupa matakuliah yang menjadi prasyarat bagi mahasiswa untuk bisa mengikuti program ini. Fokus kajian ini adalah upaya mendeskripsikan Implementasi Praktik Pengalaman Lapangan (PPL) bagimahasiswa program studi pendidikan bahasa Inggris Fakultas Keguruan dan Ilmu Pendidikan Universitas Islam Lamongan yang dilaksanakan oleh tujuh mahasiswa yang tergabung dalam kelompok mahasiswa di SMK Negeri 1 Lamongan tahunak ademik 2018-2019 dari keseluruhan tujuh unit SMA/SMK Mitra kerja dan sebanyak 51 mahasiswa. Data diperoleh melalui kegiatan observasi berperan serta, wawancara, dan dokumentasi selanjutnya di analisa dengan menerapkan proses pengumpulan, reduksi, dan penarikan kesimpulan. Hasil pembahasan menunjukkan bahwa praktik pengalaman lapangan (PPL) mahasiswa di SMK Negeri 1 Lamongan sebagai upaya penguatan calon guru menjadi pendidik profesional dapat terlaksana dengan memuaskan, mulai dari tahap persiapan, pembekalan, pembuatan program kerja yang meliputi: perangkat pembelajaran, pelaksanaan praktik mengajar, keterlibatan mahasiswa dalam kegiatan ektra kurikuler, pembelajaran pada bidang layanan khusus dan penilaian yang dilakukan oleh guru pamong dan dosen pembimbing.
\end{abstract}

Kata kunci: Implementasi PPL, Mahasiswa Prodi Pendidikan Bahasa Inggris

\section{Pendahuluan}

Konstruksi Praktik Pengalaman Lapangan (PPL) diasumsikan sebagai wahana mahasiswa melakukan kegiatan mengajar di sekolah mitra untuk menerapkan ilmu pengetahuan dan ketrampilan yang telah diterima selama proses pembelajaran di kampus, mengintegrasikan teori dan praktik lapangan untuk bisa memperoleh pengetahuan dan kompetensi mewadahi sesuai dengan program studi yang digeluti. Hamalik (2005) mengemukakan bahwa praktik pengalaman lapangan merupakan serangkaian kegiatan yang diperuntukkan mahasiswa calon guru yang meliputi latihan mengaja rmaupun latihan di luar kegiatan mengajar sebagai wahana membentuk dan membina kompetensi profesional yang dipersyaratkan oleh profesi keguruan. Pengalaman praktik di lapangan memiliki setidaknya dua kegiatan utama yang harus dicapai. Kegiatan tersebut meliputi pembelajaran dan pengelolaan adminstrasi di satuan unit pendidikan. Praktik pembelajaran adalah latihan melaksanakan kegiatan pembelajaran oleh mahasiswa di dalam kelas, mulai dari pengembangan silabus, mendesain perencanaan pembelajaran (RPP), pelaksanaan dan penilaian pengajaran. Sedangkanpraktik pengelolaan administrasi adalah latihan melaksanakan tugas administrasi sekolah, administrasi keguruan, layanan bimbingan, layanan khusus, dan kegiatan lainnya. Dalam melaksanakan tugas PPLini mahasiswa dipandu oleh pihak Sekolah (Pimpinan, 
tenaga kependidikan, dan guru pamong) serta dibimbing olehDosen Pembimbing Lapangan (DPL).

Harapan dengan program praktik pengalaman lapangan adalah terwujudnya pribadi calon pendidik yang memiliki abstraksi tinggi berupa kompetensi keilmuan dan pedagogis atau keterampilan dibidang pengajaran sesuai dengan disiplin ilmu yang diambil serta memiliki komitmen tinggi berupanilai, sikap, dan polatingkahlaku dalam melaksanakan tugas dan tanggung jawab penyelenggaraan pendidikan. Calon pendidik yang memiliki kualifikasi profesional yang diperlukan bagi profesinya, cakap dan tepat menggunakannya di dalam penyelenggaraan pendidikan dan pengajaran. Kehadiran calon guru profesional ini diharapkan mampu menjawab kebutuhan tenaga pendidik pada dunia pendidikan saat ini yang masih jauh dari harapan. Problem keguruan yang pernah disinyalir oleh Sudjana (1998) yang berkisar pada kompetensi profesional, pedagogis, dan kepribadian. Sampai saat ini problem personal guru di atas masih menjadi kendala dalam menyelenggaraan pendidikan, disamping problem kelembagaan yang berkaitan dengan pemerataan tenaga pendidik dan isu kesejahteraan guru.

Problema rendahnya profesionalitas guruyang secara umum sedang terjadi menjadi fokus utama penyiapan calon guru profesional melalui praktik pengalaman lapangan (PPL) disamping sebagai wahana konskruksi pengetahunan dan ketrampilan praktis di lapangan, juga diarahkan pada menjawab persoalan kelemahan guru saat ini untuk mendapatkan perbaikan dalam proses pembelajaran oleh lembaga penyedia calon guru termasuk Prodi Pendidikan Bahasa Inggris FKIP Universitas Islam Lamongan.Mulyasa (2007) menyebutkan terdapat tujuh indikator lemahnya kinerja guru, antara lain: (1) rendahnya pemahaman tentang strategi pembelajaran, (2)kurangnya kemahiran dalam mengelola kelas, (3) rendahnya kemampuan melakukan dan memanfaatkan penelitian tindakan kelas, (4) rendahnya motivasi berprestasi, (5) kurang disiplin, (6) rendahnya komitmen profesi,dan (7) rendahnya kemampuan manajemen waktu. Ketujuh problema di atas lebih banyak mengarah pada persoalan kompetensi pedagogis, uatamanya pada pengelolaan kelas. Kelemahan ini selayaknya dapat perhatian serius oleh lembaga penyedia calon guru.

Persoalan di atas dapat dirangkum pada rendahnya upaya pengelolaan kelas yang belum maksimal dimiliki oleh seorang guru. Pengelolaan kelas memiliki fungsi yang jelas. Tujuan pengelolaan kelas adalah untuk menciptakan dan menjaga kondisi kelas agar pelaksanaan pembelajaran dapat berlangsung dengan baik dan kondusif sesuai dengan arah yang ditetapkan. Weber dalam (Cooper, 1995) mengemukakan mengenai pandanganpandangan yangbersifat filosofis dan operasional dalam pengelolaan kelas yang menekankan pada berbagai variasi pendekatan yang diterapkan oleh guru agar dapat meningkatkan dan memelihara kelompok kelasyang efektif dan produktif, dimana pendekatan tersebut yang akan mengoptimalisasikan pengelolaan kelas. Melalui praktik pengalaman lapangan (PPL), mahasiswa diberikan kesempatan untuk mengembangkan diri dengan berbagai metode pengajaran yang pernah dipelajari pada mata kuliah kependidikan. Mahasiswa juga diberikan kesempatan untuk mempelajari dan mempraktikkan aktifitas kependidikan meliputi; layanan administrasi sekolah, administrasi keguruan, perpustakaan, laboratorium bahasa, layanan bimbingan dan konseling, pramuka, serta menjadi pendamping dalam kegiatan ektra kurikuler yang diselenggarakan oleh sekolah sesuai 
dengan kompetensi, bakat, dan minat yang dimiliki oleh mahasiswa.

Praktik pengalaman lapangan untuk mahasiswa Program Studi Pendidikan Bahasa Inggris Fakultas Keguruan dan Ilmu Pendidikan Unviersitas Islam Lamongan diselenggarakan dalam semangat untuk dapat menyediakan sumberdaya guru yang profesional. Dalam pedoman akademik terumuskan visi lembaga, yaitu: menjadikan program studi pendidikan bahasa inggris pada tahun 2019 menjadi program studi unggul dalam penyelenggaraan pendidikan bahasa inggris yang dilandasi nilai keislaman, kebangsaan, dan wawasan global. Visi tersebut selanjutnya diterjemahkan dalam misi program studi pendidikan bahasa inggris sebagai berikut: (1) menghasilkan pembelajaran bahasa inggris yang berkualitas dengan berlandaskan nilai nilai keislaman, kebangsaan, dan wawasan global; (2) menghasilkan penelitian dalam bidang pendidikan bahasa inggris dengan berlandaskan nilai nilai keislaman, kebangsaan, dan wawasan global; (3) menghasilkan pengabdian kepada masyarakat dengan berlandaskan nilai nilai keislaman, kebangsaan, dan wawasan global; (4) menghasilkan kerjasama dengan lembaga-lembaga terkait di tingkat regional dan nasional sebagai pendukung tri darma perguruan tinggi. Berdasar pada visi misi di atas maka disusunlah tujuan PPL sebagai berikut; a) menerapkan berbagai kompetensi dan kecakapan keguruan secara meneyeluruh dan terintegritas dalam situasi nyata di bawah bimbingan Guru Pamong dan Dosen; b) memberikan pemahaman atas lingkungan sosial sekolah secara utuh dan menyeluruh, meliputikegiatan belajar mengajar, layanan konseling, perpustakaan, laboratorium, aspekfisik, tata administratif, serta tata kuliner dan kegiatan kependidikan; c) mengambil manfaat dari program iniuntuk dapat memiliki kecakapan keguruan secara professional.

Pelaksanaan praktik pengalaman lapangan (PPL) mahasiswa program studi pendidikan bahasa inggris FKIP Universitas Islam Lamongan tahun 20182019 diikuti oleh mahasiswa semester 7 sebanyak 51 mahasiswa bertempat di SMA dan SMK se kabupaten Lamongan. Pemilihan tempat PPL mahasiswa di SMA/SMK Negeri dikandung maksud untuk lebih memberikan semangat dan tantangan kepada mahasiwa dalam mengimplementasikan pengetahuan dan ketrampilannya di ruang nyata. Satuan unit SMA dan SMK memiliki karakteristik antara lain: (1) memiliki kompleksitas materi yang lebih tinggi; (2) karakteristik belajar siswa SMA atau SMK lebih sulit diarahkan; (3) jumlah rombongan belajar lebih banyak. Sementara dipilihnya sekolah negeri, mengingat secara umum grade akreditas sekolah negeri lebih unggul dibanding dengan sekolah swasta sehingga diharapkan lebih bisa memberikan pelatihan dan pendidikan yang memadahi kepada mahasiswa baik pada persoalan pembelajaran praktik mengajar di kelas maupun pada kegiatan non akademik lainnya.

SMK Negeri 1 Lamongan sebagai salah satu lokasi praktik pengalaman lapangan merupakan sekolah menengah kejuruan tertua di Lamongan. Terletak di jalan protokol yang menghubungkan Jakarta-Surabaya. Saat ini SMK Negeri 1 Lamongan mengelola 10 kompetensi keaahlian dengan jumlah peserta didik yang dibina sebanyak 1609 siswa yang terdiri dari 30 rombongan belajar. SMK negeri 1 Lamongan termasuk sekolah projek penerapan kurikulum 2013 yang telah disesuaikan dengan kondisi sekolah, lingkungan masyarakat, serta usaha penyempurnaannya. Jumlah rombongan belajar yang besar sangat memadai untuk 
digunakan sebagai praktik penglaman lapangan bagi mahasiswa jurusan bahasa inggris Fakultas Keguruan dan Ilmu Pendidikan Universitas Islam Lamongan. Demikian pula dengan dukungan fasilitas sekolah yang memadai, budaya dan iklim sekolah yang telah terbangun serta diperkuat dengan pelaksanaan ISO 9001:2015 serta berbagai aktifitas non akademik, berupa ektra kurikuler yang diselenggarakan oleh sekolah.

\section{METODE}

Penulisan ini menggunakan metode deskriptif kualitatif, sebagaimana yang diungkapkan oleh Bogdan dan Taylor (dalam Arif Furchon 1992) bahwa penggunaan metode deskriptif adalah prosedur penelitian yang menghasilkan data deskriptif berupa ucapan atau tulisan dan berperilaku yang dapat diamati dari orang-orang atau subjek itu sendiri. Pengumpulan data dilakukan dengan teknik observasi berperan serta (participant observation), wawancaramen dalam (indepth interviewing), dan studi dokumentasi (study of documents). Analisis data merupakan kegiatan mencari dan menyusun secara sistematis data yang diperoleh dari catatan lapangan, hasil wawancara, dan bahan-bahan lain, sebagaimana saran Miles, Huberman dan Saldana (2014), sehingga temuannya dapat difahami dan diinformasikan kepada orang lain. Peneliti melakukan proses pengumpulan, reduksi, dan interpreting/concluding data. Berikutnya dilakukan pengujian keabsahan data melalui teknik triangulasi.

Subjek penelitian adalah praktik pengalaman lapangan mahasiswa program studi pendidikan bahasa inggris FKIP Universitas Islam Lamongan tahun 20182019 di tempatkan di Sekolah Menengah Atas (SMA) dan Sekolah Menengah Kejuruan (SMK) di kabupaten Lamongan. Secara keseluruhan jumlah peserta adalah 51 mahasiswa yang akan ditempatkan di tujuh lembaga SMA/SMK. Kelompok di bagi berdasarkan pada kemampuan sekolah dalam menerima mahasiswa peserta PPL, sehingga jumlah masingmasing kelompok tidak sama. Khusus kelompok yang ditempatkan di SMK Negeri 1 Lamongan berjumlah 7 mahasiswa, yaitu: Ariani Widoretno Asmoro, Maulidifi Ajrin Karimata, Lilys Nur Chindrya P.M., Aliatun Ni'am Q., Fiqrotul Ainiyah, Vera Vrentina, Heraldy Agustian Ramdhani. Mereka dibina oleh dosen pembimbing dari kampus dan tiga guru pamong, Dra. Yayuk Indarti, Drs. Purwadi, dan Akhzaroh Wahidah, S.Pd yang mendampingi dari SMK Negeri 1 Lamongan.

\section{HASIL DAN PEMBAHASAN}

Mahasiswa program studi pendidikan bahasa inggris Fakultas Keguruan dan Ilmu Pendidikan Universitas Islam Lamongan yang berhak mengikuti praktik pengalaman lapangan adalah mahasiswa semester 7 yang telah lulus dalam menenpuh mata kuliah prasyarat PPL dengan minimal nilai $\mathrm{C}$. Mata kuliah prasyarat tersebut antara lain: Mahasiswa yang diperkenankan melaksanakan PPL adalah mahasiswa yang memenuhi prasyarat berikut:1) pengantar ilmu pendidikan, 2) perkembangan peserta didik, 3) sosiologi pendidikan, 4) supervisi dan administrasi pendidikan, 5) material and curriculum development (pengembangan perangkat pembelajaran dan kurikulum), 6) profesi pendidikan, 7) teaching assessment development, dan 8) microteaching.

Praktik pengalaman lapangan diawali dengan dengan persiapan dan pembekalan yang dilaksanakan di kampus. Kegiatan persiapan lebih banyak bersifat administratif yang dikoordinir oleh ketua program studi, kegiatan mana memastikan seluruh peserta telah memenuhi persyaratan akademik, mahasiswa sudah selesai menempuh mata kuliah prasyarat 
dan sudah terdaftar sebagai mahasiswa semester 7 (tujuh), semua syarat administratif sudah terkoneksi dengan sistem informasi manajemen yang bisa di cek di laman sisfo.unisla.ac.id/ yang telah diberlakukan di lingkungan Univetsitas Islam Lamongan. Persiapan beriikutnya dilakukan di tingkat sekolah, dimana panitia melakukan konsultasi awal perihal izin dan kesiapan sekolah untuk ditempati mahasiswa PPL, setelah semuanya memungkinkan dilanjut dengan proses perizinan formal. Konsultasi dengan pihak sekolah dilakukan dengan menghitung jumlah rombongan belajar kaitannya dengan berapa jumlah mahasiswa yang bisa ditampung sampai pada melakukan inisiasi dengan guru pamong perihal pembagian tugas mengajar. Berikutnya dilakukan pembekalan di kampus berkaitan dengan penajaman materi kurikulum bahasa inggris SMA dan SMK, pengelolaan kelas, dan pembuatan perangkat pembelajaran dengan melibatkan dosen pendamping serta guru mata pelajaran bahasa inggris SMA dan SMK. Masuk dalam rangkaian pembekalan adalah dilaksanakannya seminar nasional dengan tema "Optimalisasi Peran Pendidikan dalam Menghadapi Revolusi Industri 4.0".

Sesi persiapan dan pembekalan di kampus juga digunakan untuk memberikan pemahaman kepada mahasiswa terkait tata laksana dan berbagai aturan yang harus dipatuhi mahasiswa peserta PPL selama melaksanakan praktik mengajar. Berbagai pengaturan PPL dibukukan dalam bentuk pedoman akademik pelaksanaan praktik pengalaman lapangan yang telah mencakup keseluruhan kegiatan, mulai dari tujuan, tata tertib, materi sampai pedoman penilaian yang harus menjadi acuan seluruh civitas akademika dalam melaksanakan program PPL. Selesai persiapan dan pembekalan di kampus di lanjutkan dengan penyerahan mahasiswa kepada sekolah tempat PPL sekaligus melaksanakan pembekalan teknis di sekolah secara bersama-sama antara dosen pendamping dan guru pamong atas fisilitasi kepala sekolah. Salah satu hasil dari persiapan dan pembekalan di sekolah ini adalah tersusunnya jadwal mengajar dan kegiatan mahasiswa PPL di sekolah.

Langkah pelaksanaan PPL adalah membuat rencana kegiatan dimana dalam pembuatannya berdasarkan kondisi lapangan, program sekolah dan arahan gurupamong serta dosen pembimbing, meliputi:
A. Mengenal sekolah melaksanakan PPL tempat Sekolah)

1. Dalam penahapan latihan PPL, pengenalan lapangan (sekolah tempat praktikan melaksanakan PPL) merupakan tahap awal. Kegiatan pengenalan lapangan ini dilakukan sebelum kegiatan PPL secara terjadwal dimulai.

2. Aspek aspek kehidupan sekolah yang perlu dikenali melalui wawancara dan instrumen observasi (lihat Lampiran2), antara lain sebagai berikut:
a. Keadaan fisik sekolah, lingkungan dan tata tertibnya.
b. Sarana, prasarana, dan fasilitas, termasuk sumber belajar.
c. Perangkat administrasi kelas dans ekolah.
d. Jenis-jenis program kurikuler dan ekstrakurikuler yang tersedia di sekolah.
e. Struktur organisasi dan personalia/kepegawaian sekolah.
f. Kehidupan sosial (hubungan antara siswa, guru, serta personalia lain) dalam waktu belajar dan waktu istirahat.
g. Membuat peta kerawanan kelas dengan mengikuti petunjuk- 
petunjuk dari petugasyangberwenangdisekolah.

B. Mengenal proses pembelajaran dan aktivitas siswa

1. Untuk menemukan model pembelajaran, praktikan wajib mengobservas iproses pembelajaran yang dilakukan guru pamong minimal 3 kali, sedapat mungkin pada kelas yang berbeda. (lihat Lampiran 4a).

2. Untuk menambah pengalaman pembelajaran, praktikan wajib mengobservasi pembelajaran oleh sesama praktikan minimal 3 kali, sedapat mungkin pada praktikan yang berbeda. (lihat Lampiran $4 b$ )

C. Melaksanakan pembelajaran

1. Praktikan wajib melaksanakan pembelajaran minimal 8kali. Untukitu, praktikan wajib menyusun Silabus dan/ atau Rencana Pelaksanaan Pembelajaran-RPP. (lihat Lampiran 5)

2. Silabus dan/atau RPP wajib dikonsultasikan kepada Guru Pamong dan Dosen Pembimbing PPL.

3. Penilaian pembelajaran praktikan dilakukan oleh Guru Pamong.

D. Membuat alat peraga untuk kepentingan pengajaran

E. Mengerjakan tugasa dministrasi/ ketatausahaan, dengan bimbingan wali kelas dan kepala sekolah atau petugas lain yang mewakilinya, praktikan berlatih/ berpartisipasi

Pedoman di atas telah dilaksanakan sepenuhnya oleh mahasiswa PPL di SMK Negeri 1 Lamongan dengan penuh kreatifitas dan bertanggungjawab berupa program program kerja yang meliputi jadwal pengajaran di kelas dan kegiatan bantuan administrasi, jadwal kegiatan pembina ekstra kurikuler, dan jadwal piket. Konsistensi kerja kelompok SMK Negeri 1 Lamongan ini menghasilkan dalam penyelenggaraan ]administrasi sekolah.

F. Berlatih/ berpartisipasi dalam pemeliharaan dan pendayagunaan sarana pengajaran. Kegiatan ini dilakukan antara lain dalam hal pengelolaan perpustakaan dan laboratorium.

G. Berlatih/ berpartisipasi dalam pembinaan kegiatan kokurikuler dan ekstrakurikuler.

H. Menyelenggarakan kegiatan lain. Praktikan dianjurkan melakukan kegiatan-kegiatan lain, seperti hal-hal berikut:
1. Membimbing pengisian majalah dinding.
2. Mengikuti upacara-upacara sekolah.
3. Mengikutipertemuanataurapat- rapatsekolah.
4. Melaksanakantugaspiket.

I. Menghadiri pertemuan dengan Dosen Pembimbing dan Pembina mata kuliah sebagaimana jadwal yang ada.

J. Membuat laporan

1. Buku Pribadi yang terdiri dari Buku Harian.

2. Laporan akhir dibuat 3 eksemplar, untuk praktikan yang bersangkutan, pihaksekolahterkait, dan Dosen Pembimbing PPL
K. Menempuh ujian
lisan pertanggungjawaban PPL pada Dosen Pembimbing dalam rangka menentukan nilai final.

prestasi sebagai kelompok tercepat dalam menyerahkan laporan pelaksanaan PPL kepada panitia. Laporan PPL yang memuat profil lengkap SMK Negeri 1 Lamongan hasil observasi dan dokumentasi, program kerja harian, jadwal pengajaran yang melebihi ketentuan dari minimal 8 kali pertemuan, berikut dilengkapi dengan perangkat pembelajaran yang pembuatannya telah dikolaborasi dengan 
guru pamong, dan laporan kajian individu atas keunikan belajar peserta didik. Kegiatan bantuan pada layanan administrasi sekolah juga terdokumentasi dengan baik, begitu juga dengan jadwal kegiatan ektra kurikuler yang dilakukan oleh masing-masing mahasiswa dalam membina siswa sesuai dengan kompetensinya. Seiring dengan pembahasan ini adalah penjelasan Rosidi (2007) bahwa guruadalah pekerjaan yang membutuhkan adanya kesimbangan pengetahuan teoritik dan ketrampilan teknis. Sementara Mantja (2002) menyatakan bahwa peningkatan kompetensi guru ditujukan pada aspek kognitif, afektif, dan psikomotor.

Fathurrahman (2013) menyatakan bahwa menjadi guru profesional dituntut untuk selalu mengembangkan diri sejalan dengan kemajuan ilmu pengetahuan, teknologi, danseni. Faktor ini menentukan keberhasilan guru, demikian pula yang telah diterapkan oleh mahasiswa praktik pengalaman lapangan di SMK Negeri 1 Lamongan berhasil stres terkait dengan beban tugas yang dijalankan sehingga PPL bisa berjalan dengan baik. Salah satunya adalah kemampuan mahasiswa dalam mengenali masalah dan mencari formula solusi untuk melakukan tindakan kreatif. Berikut adalah beberapa masalah dan solusi yang telah dirumuskan oleh kelompok mahasiswa PPL, antara lai: (a) adanya perbedaan format perangkat pembelajaran, antara yang sudah dipersiapkan dari kampus dengan kondisi riil di lapangan. Solusi yang diambil adalah dengaan melakukan sinkronisasi berdasarkan pada kurikulum yang diberlakukan atas arahan dari guru pamong; (b) benturan waktu antara totalitas praktik mengajar di lapangan dan masih adanya mata kuliah yang harus ditempuh. Solusi yang diambil adalah bersifat individual dan kelompok, untuk yang bersifat kelompok adalah bersama dosen

pengampumatakuliahmerubahjadwalperku liahan yang tidak berbenturan dengan praktik mengajar di kelas, sementara yang bersifat individu diselesaikan secara kasuistik; (c) kedisiplinan mahasiswa sudah baik meski perlu ditingkatkan, halmana karena adanya kegiatan di kampus serta pemahaman tugas dan kewajiban yang belum maksimal ketika berada di sekolah; (d) praktik mengajar, kemampuan mahasiswa dalam melaksanakan praktik mengajar tidak sama, permasalahan klasik ada pada pengendalian kelas yang belum maksimal, solusi yang ambil adalah dengan tim teaching dan senantiasa meningkatkan kemampuan pengenalan peserta didik. Pengenalan masalah dan kemampuan melakukan pemecahannya ini akan berdampak pada profesionalitas calon guru yang oleh Glickman (1981) digambarkan bahwa guru profesional adalah guru yang memiliki komitmen dan abstraksi tinggi hal mana relevan dengan tiga ciri guru profesionalyang diberikan Sahertian (1992), yaitu; a) ekspert dalam tugas mengajar dan mendidik. b) memiliki tanggung jawab profesional, c) memiliki rasa kesejawatan.

Bagian penting dalam pelaksanaan PPL adalah melakukan penilaian yang dilaksanakan oleh antar mahasiswa, guru pamong, dan dosen pembimbing berdasarkan pedoman penilaian yang telah diatur oleh kampus dimana penilaian mesti bersifat terbuka, berkesinambungan, dan membimbing. Komponen yang dinilai antara lain; kemampuan menyusun dokumen perangkat pembelajaran, kemampuan melakukan proses pembelajaran, penampilan diri selama melaksanakan PPL, kemampuan berinteraksi dengan lingkungan sekolah, kemmampuan kerjasama tim, kemampuan melakukan evaluasi pembelajaran, dan kemampuan membuat dokumen pelaporan 
akhir pelaksanaan PPL. Penilai yang dilakukan juga mengikuti saran Pidarta (1999) dimana dalam pelaksanaan observasi kelas yang perlu perhatikan antara lain; a) suasanakelas, b) cara memulai dan menutup pelajaran, c) kecocokan metode yang dipakai dengan materi pelajaran, d) penggunaan media pendidikan, e) cara mengaktifkan siswa, f) tugas berstruktur yang diberikan, g) perkembangan afeksif siswa, $h$ ) pemahaman dan penalaran siswa dari segi kognisi, serta i) kemampuan siswa dalam bidang psikomotor.Untuk masing-masing mahasiswa dilakukan penilaian bersama antara guru pamong dan dosen pembimbing, dimana hasil penilaiannya ditabulasi untuk menjadi nilai final hasil pelaksanaan praktik pengalaman lapangan secara individu menggunakan rentang nilai $0,0-49=\mathrm{E}$ (sangat kurang), 5,0 - 5,5 = B (kurang), 5,6 - 6,5 = C (cukup), 6,6 - 7,9 = B (baik), dan 8,0 -10,0 = A (sangat baik).

Implementasi praktik pengalaman lapangan program studi pendidikan bahasa inggris FKIP Universitas Islam Lamongan dapat dijelaskan secara utuh melalui gambar berikut:

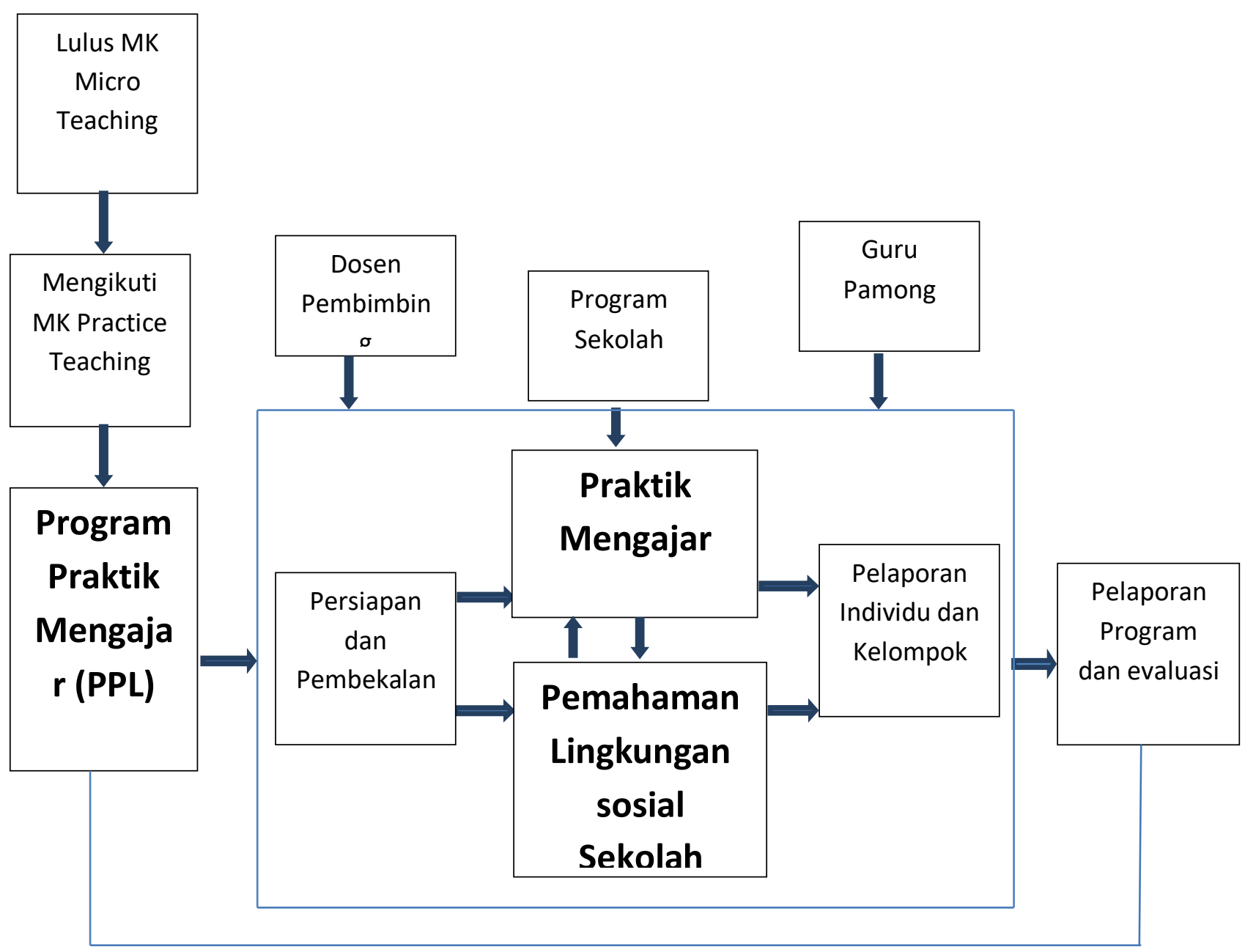




\section{KESIMPULAN}

Berdasar padaKajian tentang
implementasi praktik pengalaman lapangan mahasiswa program studi pendidikan nahasa inggris di atas, maka dapat ditarik kesimpulan antara lain: PPL adalah kegiatan yang didesign untuk memberikan penguatan kepada mahasiswa sebagai calon guru dalam mempersiapkan diri sebagai guru profesional, memiliki komitmen dan abstraksi yang tinggi serta terampil dalam pengelolaan kelas. Pelaksanaan PPL dilakukan mulai dari tahap persiapan dan pembekalan, pembuatan program kerja yang meliputi: perangkat pembelajaran, pelaksanaan praktik mengajar, keterlibatan mahasiswa dalam kegiatan ektra kurikuler, pembelajaran pada bidang layanan khusus. Akhir pelaksanaan mahasiswa praktik pengalaman lapangan membuat laporan pelaksanaan yang memuat keseluruhan kegiatan baik individu maupun kelompok, sebagai bagian dari proses PPL sekaligus bagian akhir proses penilaian yang dilakukan oleh guru pamong dan dosen pembimbing.

\section{Daftar Pustaka}

Bogdan, R.C. dan Taylor, S.J. Pengantar Metode Penelitian Kualitatif (suatu pendekatan Fenomenologis Terhadap IlmuIlmu Sosial)Terjemahan Arief Furchan (Surabaya; Usaha Nasional, 1992), 21.

Cooper, J. M. 1995. Classroom teaching Skills. Lexington : D.C. Heath andCompany.

Fathurrahman. 2013. Pembinaan profesional guru dalam perspektif teoritis dan praktis. Jurnal Ilmu Sosial dan Humaniora Volume 1 nomor 2 tahun 2013 LPPM Universitas Islam Lamongan.
Glickman, C.D. 1981. Developmental Supervisiorr. Alexandria: ASCD.

Hamalik, O. 2005.Pendidikan Guru BerdasarkanPendekatanKompet ensi.Jakarta: BumiAksara.

Mantja,

$\mathrm{W}$. 2002.Manajemenpendidikandan supervisipengajaran. Malang: Wineka Media

Miles, M. B., Huberman, A. M., \& Saldana, J. 2014. Qualitative data analysis: a methods sourcebook. Sage Publications, Inc.

Mulyasa, E. 2007. Standar Kompetensi dan Sertifikasi Guru. Bandung: PTRemaja Rosdakarya.

Pidarta,

M. 1992.PemikiranTentangSupervis iPendidikan, Jakarta, BumiAksara.

Rosidi, S. 2008, PenelitianTindakan, PraksisPendidikProfesional.

MakalahSeminar danLokakaryaNasional, KerjasamaDinasPendidikandan KebudayaanProvinsiJawaTimur dan PP Un-Nur Malang, tanggal 25 Mei 2008

Sahertian, P. A. 1992. Paradigmakategori guru

kaitannyadenganprofesionalisas itenagakependidikan.PidatoPeng ukuhan Guru Besar IKIP Malang.

Sudjana, N. 1998. Cara belajar siswa aktif dalam proses belajar mengajar.Bandung: Sinar Baru Algesindo

Pedoman Akedemik Program Studi Pendidikan Bahasa Inggris FKIP Universitas Islam Lamongan, 2018. 